\title{
Engaging Ethically: A Discourse Ethics Perspective on Social Shareholder Engagement
}

\author{
Jennifer Goodman \\ Daniel Arenas
}

ESADE Business School, Ramon Llull University

\begin{abstract}
The primacy of shareholder demands in the traditional theory of the firm has typically excluded marginalised stakeholder voices. However, shareholders involved in social shareholder engagement (SSE) purport to bring these voices into corporate decision-making. In response to ethical concerns about the legitimacy of SSE, we use the lens of discourse ethics to provide a normative analysis at both action and constitutional levels. By specifying three normative questions, we extend the analysis of SSE to identify a political role for shareholders in pursuit of the common good. We demonstrate the desirability for SSE to promote regulatory/ institutional change to guarantee marginalised stakeholders a voice in corporate decisions that affect them. The theory of SSE we propose thus calls into question the stark separation of the political and economic spheres and reveals an underlying tension, often overlooked, within the responsible investment literature.
\end{abstract}

KEY WORDS: social shareholder engagement, discourse ethics, communicative action, deliberative democracy, stakeholder engagement, Habermas

\section{INTRODUCTION}

\section{CHAREHOLDERS ARE JUST ONE OF THE MULTIPLE STAKEHOLDER}

$\checkmark$ groups which can affect and are affected by business firms (Donaldson \& Preston, 1995; Freeman \& Reed, 1983). The shareholder primacy orientation of traditional agency theory assumes shareholders will maximise their individual utility (Jensen \& Meckling, 1976). Social shareholder engagement ${ }^{1}$ (SSE) poses a challenge to this approach, as shareholders bring the concerns of often voiceless and marginalised stakeholders, such as victims of human rights abuses and environmental degradation, to the heart of corporate decision-making (Dhir, 2012; Hennchen, forthcoming; Kraemer, Whiteman, \& Banerjee, 2013; Lee \& Lounsbury, 2011; McLaren, 2004; Proffitt \& Spicer, 2006). Yet research suggests that neglecting to consider the ethics of the process of SSE can pose a threat to its legitimacy (Dhir, 2012; O'Rourke, 2003).

The role of business firms in addressing social and environmental problems has been discussed widely in the management literature, usually under the rubric of corporate social responsibility (Garriga \& Mele, 2004; Jamali, 2008). Perspectives such as stakeholder democracy (Freeman, 1984; Matten \& Crane, 2005; Moriarty, 2014), 
corporate citizenship (Moon, Crane, \& Matten, 2005) and political CSR (Scherer \& Palazzo, 2007; Scherer, Palazzo, \& Matten, 2014) have defended a much broader set of responsibilities for the business firm in society. Research in the field of law (Freshfields, 2005; Stout, 2012) has also challenged the mantra of shareholder wealth maximisation by focusing on a broader interpretation of fiduciary duty. The growth in responsible investment practice (Eurosif, 2014) and research has demonstrated the plurality of demands made by shareholders and the continuously growing interest in environmental, social, and governance (ESG) issues in investment.

But what of these shareholders who purport to speak for marginalised stakeholders? Despite their oft-stated commitment to voicing unheard stakeholder concerns, and the extensive descriptive research on shareholder engagement, a normative, ethical approach has so far been neglected. Rather, the literature has focused on strategy and tactics (den Hond \& de Bakker, 2007; Lee \& Lounsbury, 2011; Rojas, M'Zali, Turcotte, \& Merrigan, 2009) or identity (Arjaliès, 2010; Rehbein, Waddock, \& Graves, 2004). Furthermore, existing research has raised concerns about how shareholders undertake SSE. These include the need to establish legitimacy in the face of a plurality of demands on the firm (Scherer \& Palazzo, 2007), the potential for shareholders to actually harm rather than help the local communities they seek to represent (Coumans, 2012; Dhir, 2012), the lack of accountability of engagement behind "closed doors" (McLaren, 2004; O'Rourke, 2003), and the use of divestment or threat of disclosure (Goodman, Louche, van Cranenburgh, \& Arenas, 2014). In addressing this gap, we provide a benchmark for reflecting on the ethics of the SSE process.

This article explores how shareholders involved in SSE can ensure they engage ethically. We structure our analysis according to the action and constitutional levels identified by Schreck et al. (2013). In this way we address SSE within existing institutional and regulatory constraints, before going on to consider to what extent and how SSE should challenge the constraints themselves to change the "rules of the game" (North, 1990: 3).

We approach our analysis through the lens of Habermasian discourse ethics (Habermas, 1984, 1987, 1992), which helps examine SSE from a much-needed normative perspective and allows for the mediation of a plurality of ethea. Particularly relevant to SSE is the Habermasian emphasis on the participation of all affected parties in fair dialogues to establish valid, moral norms (Beschorner, 2006). Another advantage of discourse ethics is that it is process-focused and therefore avoids assumptions of the moral content of norms underlying other ethical theories. Finally, the extension of discourse ethics to deliberative democracy in Habermas' later work (Habermas, 1996) is increasingly used in debates about the political role of business in society (Moon et al., 2005; Palazzo \& Scherer, 2006; Scherer \& Palazzo, 2007).

Our analysis of SSE through a discourse ethics lens enables us to develop a normative perspective of SSE, heretofore absent in the stakeholder engagement literature. This analysis identifies three normative questions related to voicing stakeholder concerns, promoting stakeholder engagement, and promoting institutional/ regulatory change. The first two questions belong to the action level and the last to 
the constitutional level. We extend the analysis of SSE beyond most work on political CSR to include the desirability of promoting regulatory/institutional change to ensure marginalised stakeholders a voice in corporate decisions that affect them. In this way we elaborate a deliberative democratic political conception of SSE, which in turn questions the stark separation of the spheres of economics and politics. Our analysis also implies a dilemma for shareholders involved in SSE as to whether they are prepared to yield power in order to ensure the participation of marginalised stakeholders. This dilemma reveals the significance of the often overlooked difference between purely ethically motivated shareholders and shareholders who may also use SSE instrumentally as a means to reduce risk.

We begin by clarifying the concept of SSE and its prevalence in practice. We then review the literature to date on SSE, which reveals the existence of ethical concerns for shareholders in SSE. We next outline discourse ethics, and present and justify this theory as our lens for developing a normative perspective of SSE. The subsequent section presents our multi-level analysis structured around three normative questions and our findings. We then explore these findings and discuss their implications for existing theory on SSE and business ethics, and their relevance to practice. We end with avenues for future research and some conclusions.

\section{SOCIAL SHAREHOLDER ENGAGEMENT}

In contrast with shareholder engagement which prioritises financial performance (Chung \& Talaulicar, 2010; Gillan \& Starks, 2007), SSE represents the choice by shareholders dissatisfied with a firm's environmental, social, governance, and ethical performance to use the "voice" rather than "exit" option described by Hirschman (1970), or the dynamics between the two, to influence company actions (Goodman et al., 2014). Shareholder engagement can be done through letter writing, asking questions at annual general meetings, filing and voting on shareholder resolutions, as well as dialogue with management or the board, either behind the scenes, or in public confrontation (Lydenberg, 2007; Sjöström, 2008).

The tradition of SSE in the US can be traced back to the 1970s when regulation changes at the US Securities and Exchange Commission (SEC) allowed social policy topics to be considered ${ }^{2}$ (Dhir, 2006; Glac, 2010; Proffitt \& Spicer, 2006). The level of SSE is increasing (Goldstein, 2011; Lee \& Lounsbury, 2011): between 2010 and 2012 over 200 institutions representing $\$ 1.5$ trillion in assets filed or co-filed shareholder resolutions related to ESG issues at US companies (USSIF, 2012). In a study of 81 of the largest companies in the US between 2000 and 2003, almost $40 \%$ of shareholder engagement through shareholder resolutions was socially or CSR-driven (Monks, Miller, \& Cook, 2004).

Religious organisations in the US are the most active filers of social policy shareholder resolutions, accounting for around $25 \%$ of all shareholder proposals each year (Copland \& O'Keefe, 2013; Proffitt \& Spicer, 2006). But research has also identified other actors involved in SSE such as NGOs, public pension funds, individuals, and unions (Guay, Doh, \& Sinclair, 2004; Proffitt \& Spicer, 2006; Sjöström, 2010; Tkac, 2006). 
Driven by principle rather than economic rationality, SSE has a different ideology to conventional market logic (Clark, Salo, \& Hebb, 2008; Lee \& Lounsbury, 2011; McLaren, 2004). One of the largest and most active coalitions of shareholders working on SSE, the Interfaith Center on Corporate Responsibility (ICCR), claims that "it is the impact on people, usually economically vulnerable people, who inspire us to act" (ICCR, 2014c). Research has highlighted the challenge of measuring the impact and success of SSE. Many studies focus primarily on shareholder resolutions in the US and their voting outcomes (Campbell, Gillan, \& Niden, 1999; Graves, Rehbein, \& Waddock, 2001; Monks et al., 2004; Rojas et al., 2009). However, this approach can be misleading, as even strongly supported resolutions are not necessarily legally binding (Engle, 2006; Levit \& Malenko, 2011; Rojas et al., 2009). Social movement theory frames SSE as a broader movement to effect social change and shape public discourse and norms by framing agendas and raising awareness of social, environmental and ethical issues (Arjaliès, 2010; Lee \& Lounsbury, 2011; Proffitt \& Spicer, 2006; Sjöström, 2010). However, as SSE moves increasingly towards private dialogue behind the scenes where it is argued to be more effective (Becht, Franks, Mayer, \& Rossi, 2009; Goldstein, 2011; Goranova \& Ryan, 2014; Logsdon \& Van Buren, 2009), its impacts and successes on the stakeholders, which SSE claims to represent, remain opaque.

\section{SSE: ETHICAL CONCERNS}

While most literature has focused on the success, strategies, and identity of SSE (Ferraro \& Beunza, 2014), in this section we highlight some of the ethical concerns which have been raised about SSE.

The motives of SSE come from a moral basis rather than an economic one; however, civil society claims, or shareholders who give voice to them, should not uncritically be assumed to be legitimate. As Scherer and Palazzo (2007: 1109) argue, it is over simplistic to conceive of the corporation as the "bad guy" representing economic interests and civil society actors as the "good guys" representing moral interests. Just as shareholders focusing on economic interests can be divided in their demands (Anabtawi, 2007; Barnea \& Rubin, 2010; Stout, 2012; Williams \& Ryan, 2007), there can be different demands coming from SSE, and their legitimacy must be established rather than assumed.

A second concern raised in the SSE literature is whether shareholders are effective representatives of stakeholder interests (Coumans, 2012; Dhir, 2012). These studies focus on the actions of a consortium of socially conscious investors who, in 2008, submitted a shareholder proposal to a Canadian multinational regarding the human rights impacts of its Guatemalan mining operations. Between 2008 and 2010 various civil society and international organisations strongly condemned the mine's contamination of the local environment and the associated significant health risks posed for the local community. The condemnations called for a suspension of the mine's operations until the negative impacts could be addressed. The 2008 proposal was withdrawn and the company agreed to its demands for an independent human rights impact assessment. However, the proposal attracted much controversy. 
Before the Guatemalan government could implement the recommendations of the civil society organisations and suspend the mine's activities, the company announced its own action plan to address the issues raised. The human rights organisations and affected local communities were highly critical of their exclusion both from the drafting of the shareholder proposal, and from participating in any direct management or oversight of the assessment process. The engagement was seen to have provided a "whitewashing" of the situation for the company and its shareholders while harming and undermining the demands of the local community (Dhir, 2012). Thus, the need for shareholder resolutions to appeal to "the business or affairs of the corporation" (Dhir, 2012: 106) led to the divergence of interests: risk mitigation by investors on one hand, versus the complete cessation of mining operations by the local community. The concern arises as to how SSE can avoid doing harm, albeit unwittingly, to the stakeholders whose interests they strive to defend.

Thirdly, as noted in the previous section, it is behind-the-scenes dialogue which is said to represent the vast majority of shareholder engagement and where much of the real "action" happens. In light of SSE's purported proximity to stakeholders and civil society, the need for shareholders to gain the trust of those stakeholders, and to report the effectiveness of SSE, it is uncertain whether "closed door" engagement can provide the transparency and accountability demanded of SSE (McLaren, 2004; O'Rourke, 2003). Despite its importance, very little research has been done on behind-the-scenes engagement (Rehbein, Logsdon, \& Van Buren, 2013), not least due to the lack of data resulting from the confidential nature of many dialogues.

Finally, from a legal viewpoint, the notion of shareholder democracy has become popular (Anabtawi \& Stout, 2008; Bebchuk, 2005). Following this approach, greater shareholder equality achieved through empowering minority shareholders, a group which generally includes SSE shareholders (Clark et al., 2008), should go hand in hand with a greater shareholder responsibility to both the firm and other shareholders (Anabtawi \& Stout, 2008). With more power, questions about how to use it become more relevant. Shareholder tactics such as the threat to "exit" or divest from the company if their demands are not met (Admati \& Pfleiderer, 2009; Goodman et al., 2014) could be interpreted as coercive and therefore raise ethical questions about which are the appropriate tactics for SSE.

Research has primarily taken a descriptive and empirical approach to exploring SSE. However, as explained in this section, this research has identified ethical concerns about SSE, such as the need to establish legitimacy in the face of a plurality of demands on the firm, the potential for shareholders to actually harm rather than help those they seek to represent, the lack of accountability of engagement behind "closed doors," and the use of divestment or threat of disclosure. The following section presents the theoretical lens selected for our analysis and its appropriateness for establishing a normative perspective on SSE.

\section{SSE THROUGH THE LENS OF DISCOURSE ETHICS}

In this section we outline a Habermasian discourse ethics approach and argue that it is appropriate for the analysis of SSE for 3 main reasons: 1) it focuses on the 
participation of affected parties; 2) it focuses on the process avoiding assumptions about moral content and offering a means to include a plurality of worldviews and ethea; and 3) it has recently become popular for exploring new aspects of CSR such as the political role of firms and the notion of corporate citizenship, thus opening up discussion of broader implications of SSE.

\section{Habermasian Discourse Ethics}

Habermasian discourse ethics is a normative, process-oriented ethical theory. It is centred on the process of reaching valid, moral norms through participating in fair dialogues (Beschorner, 2006; Habermas, 1984, 1987). These dialogues offer an opportunity to deliberate a wide variety of worldviews and ethea and to develop a norm, which all participants can accept. Habermas states that for a norm to be valid it must fulfill the principle of universalisation:

"All affected can accept the consequences and the side effects its general observance can be anticipated to have for the satisfaction of everyone's interests (and these consequences are preferred to those of known alternative possibilities for regulation)" (Habermas, 1992: 65 emphasis in original).

According to this principle, the universal validation of a norm is dependent on consensus achieved through discursive legitimacy rather than solely on individual reflection as other philosophers such as Kant and Rawls have suggested ${ }^{3}$ (Gilbert \& Rasche, 2007; McCarthy, 1992: viii; Unerman \& Bennett, 2004). Habermas (1992: 68) states, "the justification of norms and commands requires that a real discourse be carried out and thus cannot occur in a strictly monological form, i.e., in the form of a hypothetical process of argumentation occurring in the individual mind."

Habermas then develops a second principle, which introduces the ethics of discourse:

"Only those norms can claim to be valid that meet (or could meet) with the approval of all affected in their capacity as participants in a practical discourse." (Habermas, 1992: 66 emphasis in original)

Habermas argues that only through the process of "communicative action," whereby a plurality of affected actors seek "rationally to motivate" each other through speech acts can the universal validity of a moral norm be tested (Habermas, 1992: 58 emphasis in original). Communicative action is contrasted to "strategic action" where actors aim to influence, manipulate or coerce others through sanctions or gratification. Strategic action is a concern for Habermas because its objectives are "power, economic efficiency, or other egocentric aims" (Smith, 2004: 319) and it seeks to achieve individual success (Habermas, 1984). In contrast, communicative action adopts an attitude "oriented to reaching understanding" (Habermas, 1984: 286). To achieve communicative action, Habermas identifies rules for discourse that characterise an "ideal speech situation" (Habermas, 1992: 88). We summarise these key motifs ${ }^{4}$ below. 
Argumentation. The notion of transforming preferences through argumentation, rather than simply aggregating them, is central to Habermasian discourse ethics. The focus is on the process of argumentation rather than making moral claims on the content itself. To achieve intersubjective understanding, it is fundamental that all participants present their own arguments, interests and needs, and that they be free to introduce any assertion into the discourse. In this way arguments remain undistorted by representation by another and participants are open to criticism and questioning by others (Habermas, 1992).

Plural participation. Habermas's principle of universalisation makes clear that pluralism is an essential criterion for testing validity since "all affected are admitted as participants" (Habermas, 1992: 66). This perspective is formulated into a more specific rule: "Every subject with the competence to speak and act is allowed to take part in a discourse" (Habermas, 1992: 89).

Non-coercion. According to Habermas, "No speaker may be prevented, by internal or external coercion, from exercising his rights" (Habermas, 1992: 89); rights in this case refer to the right of participation and of introducing and questioning assertions and expressing interests. The aim of communicative action is reaching "rationally motivated agreement" (Habermas, 1992: 88) based on the primacy of the best argument rather than any power-related threat or incentive (Lozano, 2001).

Transparency. Communicative action also requires transparency, which in turn demands truthful arguments. Habermas states that with "every intelligible utterance" (Habermas, 1992: 136 emphasis in original) the speaker claims that the utterance is true, is right in a particular normative context, and is truthful with no intention to mislead.

\section{Discourse Ethics Relevance to SSE}

While we do not attempt to discount other ethical theories, we present our case for using discourse ethics as a compelling normative perspective to analyse SSE.

Firstly, there have been wide-ranging claims for the use of a participatory dialogue approach, such as that proposed by Habermas, by business firms in their relationships with stakeholders (Brenkert, 1992; Gilbert \& Rasche, 2007; Matten \& Crane, 2005; O’Dwyer, 2005; Reed, 1999; Unerman \& Bennett, 2004). Since shareholders in SSE are speaking for stakeholders or addressing issues which can strongly affect the lives of other stakeholders (Goodman et al., 2014; O'Rourke, 2003), discourse ethics, with its focus on the participation of all affected by decisions, is highly relevant to SSE. Discourse ethics offers a useful point of entry for analysing concerns pointed out in the previous section: stakeholder participation, transparency in behind-the-scenes engagement and the potentially misguided reframing of stakeholder demands by shareholders in SSE.

Second, discourse ethics focuses on the process of establishing moral norms by rational argumentation. As such, this perspective holds that those affected by decisions are able to reach a reasoned agreement on what outcome they seek to achieve (Dryzek, 2000) rather than assuming that they are limited to an economic or utilitarian framework. It also avoids making any (culturally restricted) assumptions 
as to the ethical content of outcomes or "material norms" (Beschorner, 2006: 127)5. If we take this perspective to shareholders involved in SSE, they would be expected to present cogent arguments and to assume that others (managers and stakeholders, including other shareholders) are capable of being convinced. Given that stakeholders can be expected to hold different worldviews (Arenas, Lozano, \& Albareda, 2009), that shareholders have been shown to have differing ethea (Lee \& Lounsbury, 2011; McLaren, 2004), and that norms can change in a pluralistic business environment (Stansbury, 2009), an approach to SSE that avoids specific ethical content and allows for mediation and deliberation of a diversity of perspectives is particularly valuable.

Finally, discussion of the political dimension of CSR (Scherer \& Palazzo, 2007; Whelan, 2012) and corporate citizenship (Moon et al., 2005) has used Habermasian discourse ethics to reflect on the direct participation of firms and stakeholders in resolving problems in society, especially global issues that escape the capacities of national governments. As such, the use of a discourse ethics perspective to analyse SSE enables us to extend the analysis of ethical questions to broader, political implications of SSE; that is, to discuss the consequences of SSE for the rules of the game at a regulatory/institutional level. It also enables us to contribute to a political view of the business firm which is concerned with the common good rather than the more frequent focus on power games with egoistic motives (Scherer et al., 2014).

As stated at the start of this section, we do not dismiss the appropriateness of other ethical theories. We do, however, briefly note some shortcomings of two other well-established alternatives. A utilitarian perspective, in addition to focusing on ethical content e.g. happiness, is perhaps not best placed to deal with the voices of marginalised or 'unheard' stakeholders which have been shown to be of concern to shareholders in SSE (Goodman et al., 2014). By emphasising the greatest happiness for the greatest number, the views of marginalised stakeholders may be disregarded. Examples of such stakeholders can be found in the social and environmental impacts on indigenous people who live on land destined for mineral or oil extraction, such as the cases of the Ogoni in Nigeria (Hennchen, forthcoming) and the Dongria Kondh in India (Kraemer et al., 2013).

A contractarian approach (Phillips, 1997) takes a more instrumental view of stakeholders. By assuming that business firms and their stakeholders act only for strategic reasons and seek mutual advantage, this approach overlooks the ability of individuals to take a position which goes beyond self-interest, and to transform their judgments upon hearing others' arguments in a deliberation process. Actions taken by shareholders in SSE have been shown to be principle-based or concerned with collective and social benefits (Lee \& Lounsbury, 2011; McLaren, 2004), thus indicating that SSE goes beyond instrumentalism. One should not rule out the possibility that shareholders in SSE are open to changing their point of view through arguments presenting better alternatives.

Discourse ethics is not without its critics. Doubts are raised even by Habermas himself about the possibility of attaining an ideal speech situation in practical discourse (Gilbert \& Rasche, 2007; Habermas, 1992; Smith, 2004). However, advocates have claimed that it is not necessary to achieve full ideal speech to benefit from the positive effects of deliberation and communicative action (Arnold, 2013; 
O'Dwyer, 2005; Scherer \& Palazzo, 2007; Unerman \& Bennett, 2004). A normative ideal has been argued to improve discursive quality (Scherer \& Palazzo, 2007), help develop authentic moral norms for dialogue (Lozano, 2001), and evaluate the interaction between NGOs and corporations (Baur and Arenas, 2014). In the responsible investment literature, McLaren (2004) suggests that norms and standards would help investors using an engagement approach assess their effectiveness and quality.

Another possible difficulty is that Habermas himself starkly separates political and economic spheres (Scherer et al., 2014), seeing deliberation as relevant primarily for "a separate, constitutionally organized political system, but not as a model for all social institutions" (Habermas, 1996: 305). However, some supporters of discourse ethics have argued for the application of deliberation in a broader context including the business environment (Gutmann \& Thompson, 2004: 32-33; Lozano, 2001). More specifically, scholars have demonstrated the applicability of discourse ethics as a normative frame for business ethics (Scherer \& Palazzo, 2007). We thus follow those who suggest that Habermas's objective of universalization, whereby all participants can accept the consequences of decisions taken through deliberation, is still a valid yardstick by which to judge the moral legitimacy of company and stakeholder actions. In particular, we apply this perspective to shareholders involved in SSE.

\section{MULTI-LEVEL ANALYSIS OF SSE}

To get a fuller picture, we divide our inquiry into two different levels, where different ethical concerns emerge. In order to avoid the normativistic fallacy of ignoring the existing practical constraints imposed by the rules of the game, we follow the distinction used by Schreck et al. (2013) of an action level, where actors face choices within a set of given constraints; and a constitutional level, where choices about the rules of the game are made. According to Schreck et al. (2013: 306) "[e]mpirical constraints cannot entirely disburden the bearer of a responsibility" which "implies the obligation to discover a "can"". This implies examining the constitutional level as well as the action level. By exploring both levels, we are able to examine the choices facing SSE within the given constraints, as well as extending the analysis to consider how shareholders could and should influence these constraints. We identify two normative questions at the action level, and one at the constitutional level. Table 1 pinpoints the ethical concerns and questions at each level and identifies the insights for SSE from a discourse ethics perspective. Figure 1 maps visually the engagement format in response to each of the questions. The figure shows the increasingly participatory nature of business firm decision-making on issues affecting marginalised stakeholders with the arrows representing the structure of communication between the different parties.

\section{Voicing Stakeholder Concerns}

At the action level existing laws, regulations and institutions are taken as given. As highlighted in the "Social Shareholder Engagement" section of this paper, shareholders concerned with a particular environmental, social or ethical issue of company 
Table 1: Map of the empirical ethical concerns, normative questions and insights provided for SSE

\begin{tabular}{|c|c|c|c|}
\hline Level & Ethical concerns & Normative questions & Discourse ethics insights for SSE \\
\hline 思 & $\begin{array}{l}\text { Legitimacy of the plurality } \\
\text { of shareholders giving voice } \\
\text { to different marginalised } \\
\text { stakeholders (Scherer \& } \\
\text { Palazzo, 2007) } \\
\text { Shareholders harm stakeholders } \\
\text { through misalignment of } \\
\text { interests (Dhir 2012) } \\
\text { Increasingly behind the scenes } \\
\text { engagement (Logsdon \& } \\
\text { Van Buren, 2009) } \\
\text { Threat of divestment (Goodman } \\
\text { et al. forthcoming) }\end{array}$ & $\begin{array}{l}\text { Given that laws and institutions } \\
\text { are as they are, in SSE how } \\
\text { should shareholders bring the } \\
\text { voices of other marginalised } \\
\text { stakeholders to managers? }\end{array}$ & $\begin{array}{l}\text { Implement motifs of } \\
\text { communicative action: } \\
\text { - ensure community consultation } \\
\text { and consent } \\
\text { - be open to diverse perspectives } \\
\text { - better understand investment } \\
\text { beneficiaries' expectations } \\
\text { - be truthful about claims, } \\
\text { transparent about the process } \\
\text { - threat of sanctions purely to keep } \\
\text { parties involved in discourse }\end{array}$ \\
\hline 㞧 & $\begin{array}{l}\text { Perpetuation of power } \\
\text { differentials between } \\
\text { shareholders and } \\
\text { stakeholders (Dhir 2012) }\end{array}$ & $\begin{array}{l}\text { Given that laws and institutions } \\
\text { are as they are, in SSE how } \\
\text { should shareholders promote } \\
\text { engagement between business } \\
\text { firms and marginalised } \\
\text { stakeholders? }\end{array}$ & $\begin{array}{l}\text { Shareholders promote stakeholder } \\
\text { participation through: } \\
\text { - inclusion in behind-the-scenes } \\
\text { dialogue, } \\
\text { - creation of communicative fora } \\
\text { according to the motifs of } \\
\text { communicative action } \\
\text { - ensuring all outcomes are possible }\end{array}$ \\
\hline 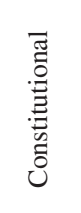 & $\begin{array}{l}\text { Institutional and regulatory } \\
\text { context affects SSE strategies } \\
\text { (Clark 2008, Dhir 2012) } \\
\text { Extending deliberative } \\
\quad \text { democracy into the economic } \\
\text { sphere (Habermas, 1996) }\end{array}$ & $\begin{array}{l}\text { Should SSEs promote changes } \\
\text { in laws and institutions so } \\
\text { that marginalised stakeholders } \\
\text { have a voice in corporate } \\
\text { decision-making? If so, how? }\end{array}$ & $\begin{array}{l}\text { Shareholders promote institutional/ } \\
\text { regulatory change to ensure } \\
\text { stakeholder voice: } \\
\text { - strive for a regulated stakeholder } \\
\text { democracy } \\
\text { - promote societal discussion }\end{array}$ \\
\hline
\end{tabular}

behaviour affecting marginalised stakeholders, choose to engage with managers to express their concerns and bring about change. With its focus on a normative ethical process, discourse ethics prompts us to ask, given that laws and institutions are as they are, in SSE, how should shareholders bring the voice of other marginalised stakeholders to managers?

In answering this question, one needs to take into account the concern of shareholders harming stakeholders whom they claim to represent. Among other reasons, this can happen because of a misalignment of interests. Dhir's example demonstrates the prioritisation of strategic action over communicative action by shareholders, whereby the desire to reduce risk or perceived risk for the company was paramount. Dhir (2012) proposes that shareholders involved in SSE establish meaningful and ongoing connections with civil society groups and gain wide community support for engagement initiatives. Shareholders should not only consult the affected communities, but also obtain community consent, when developing the resolution and further related agreements. These steps are in line with understanding SSE as a communicative action process in which stakeholders have participated to put forward their own arguments.

Secondly, shareholders who voice marginalised stakeholder concerns in SSE must be aware that other shareholders may advocate different social issues and different 
Question 1: Voicing Stakeholder

Concerns

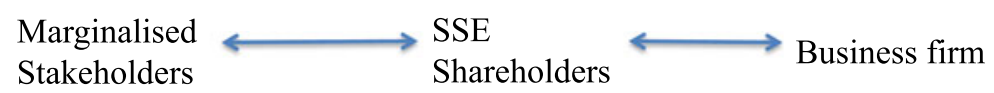

Question 2: Promoting Stakeholder Engagement

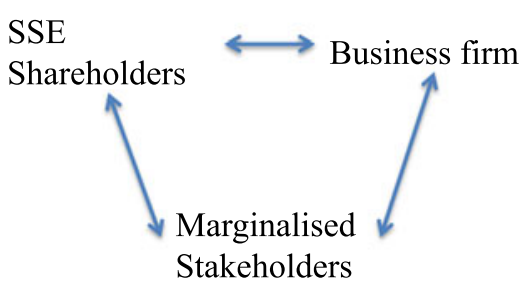

Question 3: Promoting Regulatory/Institutional Change

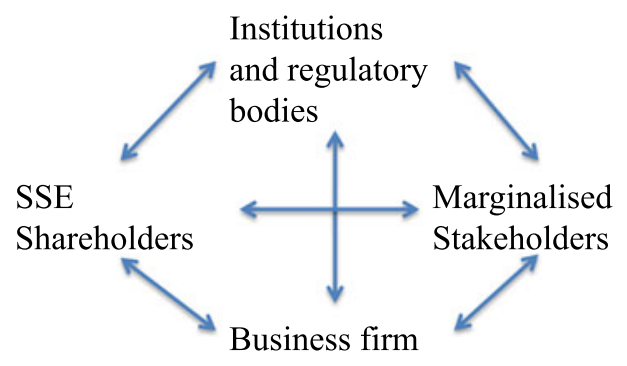

Figure 1: Engagement format in response to each question.

perspectives on these issues. Such differences might include the prioritisation by some shareholders of human rights and environmental degradation while others focus on job creation and reducing poverty (Dhir, 2012). The plurality of demands represents a challenge for both shareholders and management. From a discourse ethics perspective, shareholders should be prepared to deliberate and provide reasoned arguments to explain, question and challenge different perspectives, and should be open to changing their preferences to arrive at the common good. A process following communicative action would provide a means for shareholders and managers to address difficult issues from multiple perspectives in order to establish legitimacy and strive for an outcome that everyone can be satisfied with. In contrast, the aggregation mechanism favours the majority and does not offer the opportunity for marginalised stakeholder perspectives, often the minority, to transform the preferences of other participants.

As an extension of addressing the plurality of demands, investment funds which represent numerous individual beneficiaries, such as pension funds or mutual funds, should also consider the multiple perspectives which exist among their own beneficiaries (Ryan, 2000). The United Nations Environment Programme (UNEP) Finance Initiative sponsored research into the scope of fiduciary duty is supportive of the inclusion of ESG issues within fiduciary duty not only if they are considered to have a financial impact, but also-and of particular relevance to our argument - when a consensus is formed between beneficiaries which may be values-based (Freshfields, 2005). However, "[i]n contrast to the democratic ethical deliberation that we might assume would underpin the development of an SRI policy, mutual funds, even SRI-focused ones, generally do not involve investors in their decisions" (Richardson, 2013: 6). This implies the need for fund managers to establish communicative fora for their beneficiaries in order to 
deliberate and reach a reasoned agreement on the relative importance of different values and financial return.

Communicative action demands transparency and truthfulness in terms of the information available to participants in dialogue. Shareholders therefore must ensure that the information they present, and the arguments they make, are truthful and right, in line with the motifs of communicative action. This is even more necessary since, as shown by Vandekerckhove et al. (2007), while management is prepared to engage with shareholders on non-financial issues, it is generally with the objective of denying the truth of the allegations against them.

Further, to ensure the legitimacy of the deliberative and participatory process as required by discourse ethics (Bebbington, Brown, Frame, \& Thomson, 2007; Cohen, 1997), transparency should apply to the process itself to gain the trust of other stakeholders (McLaren, 2004). Lack of process transparency was seen as one of the main failings in the damage done to stakeholders in the Guatemalan mining example (Dhir, 2012; Murphy \& Arenas, 2010). A further example is the recent support of the obligatory reporting of corporate political spending at the SEC by over a million commentators, suggesting that information which is currently confidential is widely considered to be of public interest (Bebchuk, 2014; ICCR, 2014b). This can be contrasted with sensitive information that, while pertinent to informed and reasoned argumentation, may also be highly sensitive and fundamental to corporate strategy (e.g., market research, product development and launch, succession plans, and specific product contribution to margins). From a deliberative viewpoint, secrecy in deliberations does not violate the principle of accessibility of information if good reasons can be given for secrecy and if there is an opportunity later on to challenge the information (Gutmann \& Thompson, 2004). Even if it is behind closed doors, from a discourse ethics perspective, SSE can aspire to these aspects of transparency.

Another element to consider is that discourse ethics is centred on the strength of arguments rather than incentives and the threat of sanction. However, "exit" or the sale of shares (Hirschman, 1970), is considered to be a form of sanction in engagement (Admati \& Pfleiderer, 2009). Shareholder resolutions that disclose issues in the public domain, as well as public activism campaigns, could also be seen as threats. However, whether these threats are genuinely an obstacle to reasoned agreement through communicative action is questionable. The threats referred to here are not illegal or violent or of an insulting nature. Rather, threats of exit or disclosure could be a way of drawing attention to an issue to initiate a dialogue (Hebb, Hoepner, Rodionova, \& Sanchez, 2014; Logsdon \& Van Buren, 2009; Rehbein et al., 2013) and do not prevent participants from expressing their reasoned arguments. Alternatively, such measures by shareholders can be conceived as a means to keep the company at the discussion table, and provide motivation to reach a reasoned agreement in keeping with the aims of communicative action.

According to discourse ethics, then, shareholders should bring the voice of other marginalised stakeholders to managers by means such as: consulting communities and obtaining their consent, being open to other viewpoints, understanding investment beneficiaries' expectations, being truthful about claims and transparent about 
the process, and using threat of sanctions purely for the sake of keeping parties involved in discourse. Striving to attain, however imperfectly, an ideal speech situation of communicative action would guide shareholders voicing stakeholder concerns and working within the constraints of the rules of the game.

However, a number of problems remain. Firstly, Dhir (2012) recognises that shareholders' efforts must be situated within existing legal and regulatory frameworks and that there is an imbalance of power between stakeholders. He further claims, in line with Welcomer et al. (2000), that power differentials between shareholders and stakeholders can be perpetuated through the engagement process. Secondly, doubts remain as to what mechanisms are available to shareholders in SSE to encourage firms to enter into direct engagement with stakeholders following an ideal speech situation. Finally, one must consider, as we do at the constitutional level, whether regulation favours, or becomes an obstacle to, the alignment of interests between shareholders and the stakeholders they represent.

\section{Promoting Stakeholder Engagement}

Maintaining the regulatory, institutional and legal constraints as above, a second normative question emerges. Following the communicative action rule of participation of all affected, we consider whether it is enough to channel stakeholder views through shareholders, or if the goal of SSE should include promoting broader stakeholder participation. Thus, the question is: given that laws and institutions are as they are, in SSE, how should shareholders encourage business firms to engage in dialogue directly with marginalised stakeholders? In contrast to the first question, here the focus is on shareholders creating opportunities for direct stakeholder participation in corporate decision-making.

Through a discourse ethics lens, SSE would have the moral obligation to promote communicative fora so that firms enter into direct dialogue with other stakeholders, especially marginalised ones. Despite arguments that shareholders in the US have more limited power than their counterparts in the UK (Bebchuk, 2005), shareholders are usually considered the most powerful stakeholders (Gilbert \& Rasche, 2007; Matten \& Crane, 2005). In order to address power imbalances and move towards an ideal speech situation, it is essential to ensure the participation of other stakeholders following the motifs of argumentation, plural participation, non-coercion and transparency.

One way for more stakeholders to have access to deliberation is to invite them to participate in behind-the-scenes dialogues. Such participation must be understood with regard to the degree of sensitivity of the relevant information; non-disclosure agreements, or the de-identification of sensitive information, could facilitate such participation without jeopardising confidentiality. If information is time-sensitive, ex-post disclosure can form the basis for deliberation on future practice (Gutmann \& Thompson, 2004).

A second way to involve stakeholders is to create broader communicative fora. One such example is the US-based Interfaith Center on Corporate Responsibility (ICCR), a coalition of responsible shareholders committed to engaging on environmental, social, governance and ethical issues with companies. The ICCR holds annual 
multi-stakeholder roundtable events which bring together shareholders, stakeholders, experts and representatives from multiple companies and sectors affected by issues such as access to HIV/AIDS medication in the pharmaceutical sector, responsible marketing to children in the food and beverage sector, and the protection of water rights with companies from multiple sectors (ICCR, 2014a).

An important challenge in addressing this second normative question occurs when marginalised stakeholders themselves reject communicative action, fearing it is a "strategy of co-optation" by the company (Welcomer, Gioia, \& Kilduff, 2000: 1193). This challenge is significant because true communicative action requires the participation of all affected by the decision in order to achieve legitimate outcomes. Understanding the reasons why marginalised stakeholders do not participate becomes fundamental here. Welcomer et al. (2000) highlight a case where the local community rejected the dialogue process as "window dressing" where they would have no true power to veto the planned site. Lack of power and insufficient capacity and skills are argued to be key reasons for marginalised groups' lack of success or unwillingness to participate in deliberation (Dryzek, 2000; Gutmann \& Thompson, 2004). Welcomer et al. (2000) draw on Beck (1994) to underscore the importance of making all participants aware that key decisions are yet to be made and that all potential outcomes will be reasonably considered-in line with a discourse ethics perspective which seeks understanding rather than the strategic pursuit of individual interests.

These motifs offer opportunities for SSE to turn the business firm into a more participative and deliberative arena focusing on communicative action and the common good. Such stakeholder participation could be seen as a political space, and approaching some form of stakeholder democracy. The translation of the political concept of democracy into the economic sphere to create the notion of stakeholder democracy (Matten \& Crane, 2005) is challenging, not least because democracy is a term disputed even in politics (Moon et al., 2005). In the context of SSE, a deliberative democratic approach, which some Habermasians also advocate ${ }^{6}$, offers a particular opportunity for marginalised stakeholders to voice their concerns. Further, while democracy, understood in a more classical sense, would assume that preferences are fixed and can be determined through voting, a deliberative approach recognises that preferences can be transformed through reasoning, given time and space (Dryzek, 2000; Elster, 1998). In this way, deliberative democracy goes beyond the majority's imposition of its social preferences and existing power (Gutmann \& Thompson, 2004: 16). Rather, it allows the minority a chance to voice their arguments, address questions and criticism, and potentially change the minds of other participants. If SSE is morally obliged to promote such deliberative democratic spaces rather than merely voicing the grievances of affected stakeholders, this suggests SSE assumes a "quasi-political role" (Baur \& Arenas, 2014).

Some real-life examples show practical concerns in answering this normative question. The ICCR acknowledges that although roundtables are effective and can encourage rapid responses, they are also complicated to organise and therefore undertaken infrequently (ICCR, 2014a). SSE should also consider that not all firms or all stakeholders have the resources, the desire, or the capacity to participate 
in this type of voluntary dialogue. Similarly, O'Rourke (2003) concludes that SSE within the rules of engagement, on an issue by issue basis, is not enough, for engagement is limited to those with resources of time and money, and legal constraints limit a more fundamental critique of corporate behaviour. The result is an incremental approach rather than transformative change. This leads us to consider whether working within the given regulatory and institutional context and using the existing institutionalised channels (Lee \& Lounsbury, 2011) is sufficient for the SSE mandate.

\section{Promoting Regulatory/Institutional Change}

We expand the view of SSE from a discourse ethics perspective to raise a normative question at the constitutional level. Should SSE promote changes in regulations and institutions so that marginalised stakeholders have a voice in corporate decision-making? If so, how?

Despite the popularity of theories of the political role of corporations, few have specified which regulatory and institutional changes are necessary to ensure that firm managers hear the voices of affected parties. The regulatory environment can affect SSE directly, for example, the issues which shareholders can file on, requirements of minimum holdings over a certain time and minimum voting requirements (Clark et al., 2008; Logsdon \& Van Buren, 2009). The question is whether shareholders in SSE should not only promote voluntary stakeholder dialogue, but regulatory and institutional reforms to ensure that marginalised voices are heard. Indeed, it is hard to see what deliberative stakeholder democracy means if there are no effective institutions in place that oblige the inclusion of these voices according to the motifs specified above.

Although Habermas' work on deliberative democracy focuses on the formal political sphere rather than the economic sphere (Habermas, 1996), we build on work arguing that the economic and political divide is often blurred (Scherer et al., 2014), and suggest that shareholders concerned with social, environmental, and ethical issues affecting stakeholders also have a moral obligation to work towards the empowerment and participation of all affected stakeholders according to new institutions and the rules of the game concerning business and society relations. This reform would really be in the spirit of discourse ethics and communicative action. Rather than promoting stakeholder democracy on a voluntary basis, striving for change at the regulatory/institutional level implies some form of binding stakeholder democracy.

While much of the research in SSE focuses on the UK and US, examples of more participative corporate governance arrangements can be found in contexts such as Germany and Japan (Hendry, 2001; Kang \& Moon, 2012). According to some scholars, these countries' institutions demonstrate a concern for stakeholder interests reflecting a consensus "that businesses exist to serve the interest of society and not just to make a profit" (Hendry, 2001: 167). In Germany, sometimes referred to as a "stakeholder economy," a system of codetermination exists whereby the supervisory board, which oversees the management board, has both shareholder and employee representatives. This supervisory board holds a veto for certain types of transactions, 
determines the remuneration of the management board, and requires frequent reports on the firm's status, changes to business policy, and key issues regarding future conduct, thus providing indirect influence on executive directors (Gorton \& Schmid, 2004; Hendry, 2001; NortonRose, 2011). This is a possible step towards increased stakeholder participation at the board level, which serves the purpose of deliberating on company issues. Furthermore, in Germany, the legal responsibility of managers is to the firm rather than to shareholders (Allen, Carletti, \& Marquez, 2009). The German system could thus be considered as further along the "continuum towards the theoretical ideal speech situation" (Unerman \& Bennett, 2004: 702). However, this system continues to exclude the voices of marginalised stakeholders in its governance structure. Advancing deliberative democracy in corporate decisionmaking would also require access for citizens including marginalised groups, transparency of justifications and reasoning, and a commitment to the common good (Gutmann \& Thompson, 2004; Habermas, 1996).

Soskice (1997) warns that stakeholder democracy should not be transferred from Northern Europe to an Anglo-Saxon model of governance due to "deeply entrenched rules and rituals of participation" in each country's democratic model. However, we argue that while taking into account each country's tradition, attempts at institutional, legal, and regulatory change should also be a goal for SSE. While this is undoubtedly a daunting objective, this does not mean that it is an invalid one (Arnold, 2013).

A further challenge in responding to the question posed at this level is the criticism that deliberative democracy privileges a certain way to present one's views and involves some degree of self-restraint, discipline or formality which favours more advantaged groups in society (Dryzek, 2000; Gutmann \& Thompson, 2004). An obligation to participate in decision-making may compound concerns of cooptation held by marginalised, and often disadvantaged, stakeholders. One way to overcome this concern would be to extend our response in the previous section, to the constitutional level, in the sense that shareholders in SSE advocate rules of the game that guarantee veto power for marginalised stakeholders over decisions that affect them. In parallel, marginalised stakeholders who choose to contend this direct deliberation could be provided with resources or institutional support.

A further option for shareholders in SSE would be to promote institutions such as national ethics councils (Richardson \& Cragg, 2010). These councils should include a broad range of participants to ensure the representation of different perspectives who could then deliberate to set standards for ethical investment. Ethics councils already exist in Sweden and Norway to advise their national pension funds and have led to divestment recommendations in some companies for ethical motives (Richardson \& Cragg, 2010).

Finally, in addressing our third question of obligations of shareholders involved in SSE, we consider their role in specific public policy debates on responsible investment and marginalised stakeholder participation. It has been argued that "legal reforms must aim to create conditions for participatory ethical deliberation underpinning SRI decisions" (Richardson, 2008: 25). Recent discussion in the US (Stout, 2012) and UK (Freshfields, 2005) about the definition and nature of fiduciary duty indicates that ESG issues are entering the legal sphere. This has led to a 
broader concept of fiduciary duty as reported in our response to the first question and highlights the potential for different actors, including shareholders in SSE, to stimulate discussion at the societal level and reframe deeply entrenched assumptions.

\section{DISCUSSION AND IMPLICATIONS}

The identification and analysis of three questions through a Habermasian discourse ethics lens enabled us to develop a normative perspective of SSE heretofore absent in the stakeholder engagement literature. By dividing it into different levels, we have further extended the analysis of SSE to include the regulatory/institutional implications, contributing to a deliberative democratic political conception of SSE and going beyond the work to date on political CSR. Our analysis has a number of theoretical implications for business ethics as well as practical implications for SSE, shareholders more broadly, and managers.

\section{Implications for Theory}

The work of Habermas on deliberative democracy has been extended, taking into account the increasingly political role played by powerful business firms in the face of weak nation states (Scherer \& Palazzo, 2007; Scherer et al., 2014). Alternative conceptions of deliberative democracy to analyse the role of the business firm have also been called for (Mäkinen \& Kourula, 2012). The discourse ethics approach to SSE, when extended to the regulatory/institutional level, reveals the desirability of addressing imbalances of power and moving towards more democratic organisational structures. In other words, the moral obligation of SSE includes reflection about its ultimate role and the type of society it envisions. By suggesting that some shareholders are compelled to promote participation of various stakeholders at the firm level, and reforms in the rules of the game to make this participation possible, we echo the work on political CSR, which suggests that the boundaries between the political and economic spheres have become blurred. However, while previous work has considered the political role of the firm in global governance (Scherer \& Palazzo, 2007), or politics in the sense of power games with egoistic motives within the firm using an applied psychology perspective ${ }^{7}$, we build a normative theoretical argument for a political role for shareholders in SSE in pursuit of the common good. This perspective challenges the underlying assumptions in much of management literature that shareholders should confine themselves to purely economic matters. It follows that new approaches to understanding SSE, including deliberative theory and other ethical and political approaches, should take into account the reconceptualisation of shareholders as political agents working for the common good.

Research on political CSR has been both endorsed and criticised. A limitation noted by Scherer and Palazzo (2007: 1112) is that business firms in a political role "are neither elected nor democratically controlled by the public," thus raising questions about the legitimacy of their political activity. Rather than portraying the business firm as a monolithic and homogenous entity, by demonstrating the plurality 
of demands and the political role played by shareholders in SSE we provide insights into the often neglected motivations and influences on corporate decision-making (Holzer, 2008; Whelan, 2012). The deliberation of multiple perspectives, including those of marginalised stakeholders, according to the motifs of communicative action reinforces the view that corporations are political fields, and not only from a strategic perspective. This in turn reveals that accounts of the corporation's political role inspired by deliberative motifs need to include an internal as well as an external dimension, and the interconnections between the two, as the example of SSE demonstrates. Since they have to go through the filter of deliberation, this process also provides a means to address the concerns raised by Scherer and Palazzo (2007) about the legitimacy of claims of civil society actors mentioned above.

By drawing on Schreck's (2013) action and constitutional level analysis, we go beyond existing theorising of political CSR (Scherer \& Palazzo, 2007) and suggest that a discourse ethics perspective inevitably pushes reflection beyond voluntary agreements towards regulatory and institutional change to strengthen the participation of stakeholders, including marginalised ones. These changes would approximate what some call stakeholder democracy and would in turn limit shareholders' power in management decisions.

Shareholders in SSE face a clear dilemma: either to continue with their behindthe-scenes engagement which has been shown to be effective (Goodman et al., 2014; Hebb et al., 2014), and would in fact perpetuate their position of power as well as entailing the ethical concerns we have reported; or, to yield power to other affected stakeholders - either voluntarily, as shown in the analysis of the second question, or by promoting institutional and regulatory change. This dilemma, exposed through a discourse ethics lens, reveals a fundamental theoretical difference between SSE based on issues affecting marginalised stakeholders regardless of the instrumental returns, and the SSE of shareholders who engage with business firms on ESG issues as strategic action in order to reduce risk. This is an important distinction often overlooked in the responsible investment literature (Richardson \& Cragg, 2010; Woods \& Urwin, 2012). Introducing a deliberative democratic forum in business firm decision-making would make these distinctions evident as each party provides reasoning for their different arguments. Instrumentally motivated shareholders, even if they do SSE, are unlikely to voluntarily cede power to stakeholders (Whelan, 2012), whereas purely ethically motivated shareholders would be more accepting of such a proposal. This distinction reinforces an underlying tension within the responsible investment movement and scholarship, which has focused mostly on how responsible investors gain influence or mobilise, rather than on what they base their legitimacy and what their ultimate social and political goals are.

One way to navigate this dilemma is to reconceptualise the role of shareholders in SSE through the theory of stewardship, which has been applied to the role of managers in business firms (Davis, Schoorman, \& Donaldson, 1997; Hernandez, 2008,2012 ). In contrast to the traditional agency approach, "stewardship theorists focus on structures that facilitate and empower rather than those that monitor and control" (Davis et al., 1997: 26) and prioritise the collective interest over individual interests (Davis et al., 1997; Hernandez, 2012). Stewardship is used to refer to 
shareholders both in practice and research. The UK Stewardship Code understands shareholders as stewards of business firms encouraging purposeful dialogue on a number of corporate governance and risk management issues (FRC, 2012) or ESG concerns (Eurosif, 2013); more specifically, shareholders involved in SSE have been shown to see themselves in a stewardship role (Clark et al., 2008; Lee \& Lounsbury, 2011; Van Cranenburgh, Goodman, Louche, \& Arenas, 2012). The new role for shareholders that we have suggested could also be seen as that of stewards of the process of SSE; as champions and facilitators of a deliberative and democratic forum for corporate decision-making on issues of social, environmental and ethical concern.

\section{Implications for Practice}

As SSE continues to evolve, Habermasian discourse ethics and the rules of communicative action can provide a valuable benchmark to strive towards (Dhir, 2012; McLaren, 2004). In response to the three questions we pose, we have highlighted some steps for shareholders which each have practical implications; this section draws on the most significant.

Firstly, we review the steps that SSE should follow according to our analysis. Our first question identifies the importance of community consultation and consent, keeping an open mind to diverse perspectives, and better understanding beneficiaries' expectations. Also key are truthfulness about claims, transparency about the process, and using threat of exit or sanctions purely to keep parties involved in discourse. In response to our second question we explore the inclusion of affected stakeholders in behind-the-scenes dialogue, the use of communicative fora, and the importance of being open to all potential outcomes. At the constitutional level of analysis, the actionable steps include promoting regulatory change for a stakeholder democracy, establishing institutions such as ethics councils, stimulating societal discussion to address and reframe broader issues, and conferring veto power upon marginalised stakeholders in some cases.

Almost all of the responses to the ethical challenges we discuss would imply a considerable investment of time and money by shareholders. For example, at the action level, building ongoing links with local communities, to understand their perspectives, to consult with them and to gain consent implies a long-term involvement and commitment. Expertise may be required in community liaison and local knowledge, as well as in education to prepare stakeholders to deliberate and represent themselves in an informed and rational way (Gutmann \& Thompson, 2004; Unerman \& Bennett, 2004). The inclusion of marginalised stakeholders in behind-the-scenes engagement would imply possible costs for transport and dissemination of information. The organisation of communicative fora also poses a challenge for shareholders with limited resources and skills. At the constitutional level, the promotion of institutional and regulatory change, and educating marginalised stakeholders in deliberative democracy (Gutmann \& Thompson, 2004), also suggests a commitment of time and money and a long-term perspective . This would require political skills and legal expertise as well as reflection on ethical policy. These costs could lead, as O'Rourke (2003) suggests, to engagement being limited to those with time 
and money, especially considering the resource constraints faced by marginalised stakeholders and shareholders involved in SSE (Goodman et al., 2014).

Our analysis supports the need for reflection by mutual funds and other investment vehicles on their internal deliberative practices. As argued by Richardson (2013: 13), ethical deliberation within funds "could help inspire a critical reassessment of what a truly socially and ecologically sustainable investment portfolio should provide". Such action requires significant changes in behaviour for fund managers as well as beneficiaries.

Our analysis also has implications for business firms. Managers need to be cognizant of the diversity of shareholder demands and the extent of their potential reach. A rebalancing of power through multi-stakeholder and shareholder alliances and a growing political role for shareholders makes for a complex and challenging environment. Communicative fora based on the motifs of communicative action could be a valuable means of detecting, contemplating and addressing this range of voices. Furthermore, reforms at the regulatory/institutional level would have implications not only for publicly owned companies who deal directly with SSE at the action level but also for those business firms which do not have public ownership and are not accountable to shareholders. SSE aimed at influencing the rules of the game would want to ensure these companies are also held to account to stakeholder demands.

\section{FUTURE RESEARCH}

In developing a normative perspective to SSE, we offer an alternative view of the role of shareholders in society. Our analysis poses both empirical and theoretical challenges, and may raise many more questions than it answers. However, by developing a structured normative ethical perspective, we provide insights for future research and analysis.

First, future research should address some of the empirical issues at an action level; for example, whether an attitude of reaching reasoned agreement is present among participants in SSE and, if not, how this can be instilled. Further, to what extent do existing communicative fora promote the motifs of discourse ethics and communicative action? How much do shareholders in SSE currently promote the participation of marginalised stakeholders in their engagement?

This analysis has been undertaken from the perspective of the engager rather than the business firm. Future research into the company perspective is essential to gain insights into how the SSE process is perceived and implemented by firms. The firm is highly relevant for ethical SSE processes in terms of the importance of selecting and restricting participants, and providing truthful and accurate information and transparency, without which ethical SSE is not attainable.

The use of discourse ethics does not exhaust the ethical discussions concerning SSE; further research should explore alternative approaches such as other ethical perspectives and stewardship theory. Further consideration of power is also needed; for example, does SSE perpetuate or remedy power imbalances among different stakeholders? Regarding political CSR, an examination of the potential for deliberative democratic spaces including shareholders, other traditional 
stakeholders and marginalised stakeholders in corporate decision-making would be valuable to assess the legitimate basis for the firm to engage in global political deliberations.

Finally, the unresolved tension in the responsible investment literature between instrumental and ethical motivations needs to be explored in future research. There is great scope to differentiate between the types of investors involved in responsible investment that could reveal different underlying approaches currently aggregated under the umbrella of shareholder engagement.

\section{CONCLUSION}

By using a discourse ethics lens to examine the phenomenon of SSE, we have provided a normative, multi-level analysis which extends the current conversation on responsible investment and on political CSR to conclude that shareholders involved in SSE should take a political role, which goes beyond merely representing stakeholder voices to companies, and actually cede power to marginalised stakeholders and regulators in order to achieve their morally motivated goals.

The implications of our analysis are both theoretical and practical. Theoretically extending the existing debate on political CSR to include SSE provides a deliberative democratic political view of actors seen traditionally as economically rational. This also opens the frequently overlooked subject of conflicting motivations of shareholders in responsible investment. Practically, our analysis identifies steps for shareholders in SSE, as well as management, to practise communicative action, providing a benchmark for the inclusion of stakeholders in SSE and an important guideline for establishing standards in shareholder engagement.

While SSE does not represent the majority of shareholders, it does provide a fascinating entry point for opening up debate on the ethical responsibilities of shareholders. This debate is not only relevant to SSE but to all shareholders whose actions as owners of powerful multinationals impact countless marginalised individuals around the world. Seen in this way, an ethical consideration of shareholder engagement has not only been overlooked but is long overdue.

\section{ACKNOWLEDGEMENTS}

The authors would like to thank the editor and the three anonymous reviewers for their invaluable comments and guidance on earlier versions of our manuscript.

This work was funded in part by grant 2014FI_B2 00144 (Goodman J.), DEC SUR Government of Catalonia.

\section{NOTES}

1. Social shareholder engagement is used here in line with previous research (Goodman et al. 2014). This term was used to reconcile the variety of different terms found in the literature which refer to shareholders voicing their concerns on particular issues to companies (Eurosif, 2006). The use of the word 'social' reflects the relevance of the issue to society rather than just the shareholder. SSE refers to principlebased issues and the social, environmental and ethical impacts of corporate behaviour. It also includes some governance issues related to justice. However, those governance issues with the sole objective of improving financial returns are not included (Eurosif, 2012). 
2. For a detailed discussion of US engagement regulation and history please refer to the expansive explanations by Dhir (2006), Proffitt and Spicer (2006), Glac (2010) and Rehbein (2013).

3. While we recognise that Habermas and Kant indeed have similarities, we follow the argument laid out in this journal by Gilbert and Rasche (2007) who claim that "whereas Kantian ethics links the process of justification to the individual conducting a universalizing test (Kant, 1993, 2004) to see whether she or he wishes everyone else to act according to the same maxim, in discourse ethics Habermas (1990: 196-98) moves Kant's categorical imperative beyond its 'monological' reflection. The same criticism applies to Rawls's (1971) 'Theory of Justice,' where the morality of an action is determined by individuals critically evaluating actions behind a 'veil of ignorance.' Habermas argues that individual reasoning and self-reflection are insufficient to justify acceptable norms because different individuals might come to different conclusions regarding the acceptability of particular norms." (Gilbert \& Rasche 2007: 193, emphasis in original).

4. The term "motif" is used by Bebbington et al. (2007) to refer to the critical requirements of authentic engagement in the context of dialogic theory. In a similar way we use this term to express the critical requirements of discourse ethics.

5. An example of such an assumption is the proposed objective of stakeholder happiness enhancement from a neo-utilitarian approach (Jones \& Felps, 2013). From a discourse ethics perspective, the goal of SSE would be to achieve rational argumentation and participation in line with communicative action rather than the enhancement of the happiness of particular stakeholders.

6. Scherer and Palazzo (2007) distinguish two Habermasian conceptions of corporate social responsibility (CSR); the first focuses on ideal discourse while the second takes the more political view of deliberative discourse.

7. This review of previous research has been clearly summarised in (Scherer et al., 2014).

\section{REFERENCES}

Admati, A. R. \& Pfleiderer, P. C. 2009. The 'Wall Street Walk' and shareholder activism: Exit as a form of voice. The Review of Financial Studies, 22(7): 2445-2485.

Allen, F., Carletti, E., \& Marquez, R. 2009. Stakeholder capitalism, corporate governance and firm value, Working paper: University of Pennsylvania.

Anabtawi, I. 2007. Some skepticism about increasing shareholder power. Journal of Scholarly Perspectives, 3(1): 1-24.

Anabtawi, I. \& Stout, L. 2008. Fiduciary duties for activist shareholders. Stanford Law Review, 60(5): 1255-1308.

Arenas, D., Lozano, J. M., \& Albareda, L. 2009. The role of NGOs in CSR: Mutual perceptions among stakeholders. Journal of Business Ethics, 88(1): 175-197.

Arjaliès, D. 2010. A social movement perspective on finance: How socially responsible investment mattered. Journal of Business Ethics, 92(Supplement 1): 57-78.

Arnold, D. G. 2013. Global justice and international business. Business Ethics Quarterly, 23(1): 125-143.

Barnea, A. \& Rubin, A. 2010. Corporate social responsibility as a conflict between shareholders. Journal of Business Ethics, 97: 71-86.

Baur, D. \& Arenas, D. 2014. The value of unregulated business-NGO interaction: A deliberative perspective. Business and Society, 53(2): 157-186.

Bebbington, J., Brown, J., Frame, B., \& Thomson, I. 2007. Theorizing engagement: The potential of a critical dialogic approach. Accounting, Auditing \& Accountability Journal, 20(3): 356-381.

Bebchuk, L. 2014. The million-comment-letter petition: The rulemaking petition on disclosure of political spending attracts more than 1,000,000 SEC comment letters. http://blogs.law.harvard.edu/corpgov/2014/09/04/the-million-comment-letterpetition-the-rulemaking-petition-on-disclosure-of-political-spending-attractsmore-than-1000000-sec-comment-letters/, accessed 7th October 2014. 
Bebchuk, L. A. 2005. The case for increasing shareholder power. Harvard Law Review, 118(3): 835-914.

Becht, M., Franks, J., Mayer, C., \& Rossi, S. 2009. Returns to shareholder activism: Evidence from a clinical study of the Hermes UK Focus Fund. The Review of Financial Studies, 22(8): 3093-3129.

Beck, U. 1994. Reflexive modernization: Politics, tradition and aesthetics in the modern social order. Stanford, CA: Stanford University Press.

Beschorner, T. 2006. Ethical theory and business practices: The case of discourse ethics. Journal of Business Ethics, 66(1): 127-139.

Brenkert, G. G. 1992. Freedom, participation and corporations: The issue of corporate (economic) democracy. Business Ethics Quarterly, 2(3): 251-269.

Campbell, C. J., Gillan, S. L., \& Niden, C. M. 1999. Current perspectives on shareholder proposals: Lessons from the 1997 proxy season. Financial Management, 28(1): 89-98.

Chung, H. \& Talaulicar, T. 2010. Forms and effects of shareholder activism. Corporate Governance: An International Review, 18(4): 253-257.

Clark, G. L., Salo, J., \& Hebb, T. 2008. Social and environmental shareholder activism in the public spotlight: US corporate annual meetings, campaign strategies, and environmental performance. Environment and Planning A, 40(6): 1370-1390.

Cohen, J. 1997. Deliberation and democratic legitimacy. In J. Bohman \& W. Rehg (Eds.), Deliberative democracy: Essays on reason and politics: 67-92. Cambridge, Massachusetts: MIT Press.

Copland, J. R. \& O'Keefe, M. M. 2013. Proxy Monitor 2013: A report on corporate governance and shareholder activism. http://www.proxymonitor.org/pdf/pmr_06. pdf: accessed 13th June 2014.

Coumans, C. 2012. Mining, human rights and the socially responsible investment industry: Considering community opposition to shareholder resolutions and implications of collaboration. Journal of Sustainable Finance and Investment, 2(1): 44-63.

Davis, J. H., Schoorman, F. D., \& Donaldson, L. 1997. Toward a stewardship theory of management. Academy of Management Review, 22(1): 20-47.

den Hond, F. \& de Bakker, F. G. A. 2007. Ideologically motivated activism: How activist groups influence corporate social change activities. Academy of Management Review, 32(3): 901-924.

Dhir, A. A. 2006. Realigning the corporate building blocks: Shareholder proposals as a vehicle for achieving corporate social and human rights accountability. American Business Law Journal, 43(2): 365-412.

2012. Shareholder engagement in the embedded business corporation: Investment activism, human rights, and TWAIL discourse. Business Ethics Quarterly, 22(1): 99-118.

Donaldson, T. \& Preston, L. E. 1995. The stakeholder theory of the corporation: Concepts, evidence, and implications. Academy of Management Review, 20(1): 65-91.

Dryzek, J. S. 2000. Deliberative democracy and beyond. Oxford, UK: Oxford University Press.

Elster, J. 1998. Deliberative democracy. Cambridge, UK: Cambridge University Press.

Engle, E. A. 2006. What you don't know can hurt you: Human rights, shareholder activism and SEC reporting requirements. Syracuse Law Review, 57: 63-96.

Eurosif. 2006. European SRI Study. http://www.eurosif.org/images/stories/pdf/eurosif_ sristudy_2006_complete.pdf, retrieved 29th July 2012. 
. 2012. European SRI Study. http://www.eurosif.org/research/eurosif-sri-study/sristudy-2012, retrieved 1st December 2012.

. 2013. Shareholder Stewardship: European ESG Engagement Practices. http:// www.eurosif.org/our-work/research/archive/, retrieved 20th October 2014.

. 2014. European SRI Study. http://www.eurosif.org/semantics/uploads/2014/09/ Eurosif-SRI-Study-2014.pdf, retrieved 18th October 2014.

Ferraro, F. \& Beunza, D. 2014. Why talk? A process of model of dialogue in shareholder engagement, Working Paper Series, SSRN. London: London School of Economics.

FRC. 2012. The UK Stewardship Code. London: Financial Reporting Council Ltd.

Freeman, R. E. \& Reed, D. L. 1983. Stockholders and stakeholders: A new perspective on corporate governance. California Management Review, 25(3): 88-106.

Freeman, R. E. 1984. Strategic management: A stakeholder approach. Boston: Pitman.

Freshfields. 2005. A legal framework for the integration of environmental, social, and governance issues into institutional investment: Freshfields Bruckhaus Deringer, UNEP FI.

Garriga, E. \& Mele, D. 2004. Corporate social responsibility theories: Mapping the territory. Journal of Business Ethics, 53(1-2): 51-71.

Gilbert, D. U. \& Rasche, A. 2007. Discourse ethics and social accountability: The ethics of SA 8000. Business Ethics Quarterly, 17(2): 187-216.

Gillan, S. L. \& Starks, L. T. 2007. The evolution of shareholder activism in the United States. Journal of Applied Corporate Finance, 19(1): 55-73.

Glac, K. 2010. The influence of shareholders on corporate social responsibility. History of Corporate Responsibility Project. Working Paper No. 2. Center for Ethical Business Cultures located at the Opus College of Business, University of St. Thomas - Minnesota: 1-38.

Goldstein, M. 2011. The state of engagement between US corporations and shareholders: 1-30: IRRC Institute.

Goodman, J., Louche, C., van Cranenburgh, K. C., \& Arenas, D. 2014. Social shareholder engagement: The dynamics of voice and exit. Journal of Business Ethics, 125(2): 193-210.

Goranova, M. \& Ryan, L. V. 2014. Shareholder activism: A multidisciplinary review. Journal of Management, 40(5): 1230-1268.

Gorton, G. \& Schmid, F. A. 2004. Capital, labor, and the firm: A study of German codetermination. Journal of the European Economic Association, 2(5): 863-905.

Graves, S., Rehbein, K., \& Waddock, S. 2001. Fad and fashion in shareholder activism: The landscape of shareholder resolutions, 1988-1998. Business and Society Review, 106(4): 293-314.

Guay, T., Doh, J., \& Sinclair, G. 2004. Non-governmental organizations, shareholder activism, and socially responsible investments: Ethical, strategic, and governance implications. Journal of Business Ethics, 52: 125-139.

Gutmann, A. \& Thompson, D. 2004. Why deliberative democracy? Princeton: Princeton University Press.

Habermas, J. 1984. The theory of communicative action vol. 1: Reason and the rationalization of society. (McCarthy, T., Trans.). Boston: Beacon Press. . 1987. The theory of communicative action vol. 2: Lifeworld and system: A critique of functionalist reason. (McCarthy, T., Trans.). Boston: Beacon Press. 1992. Moral consciousness and communicative action. (C. N. Lenhardt, S. W. (trans). Trans.). Cambridge: Polity Press. 
1996. Between facts and norms: Contributions to a discourse theory of law and democracy (Rehg, W., Trans.). Cambridge, MA: MIT Press.

Hebb, T., Hoepner, A., Rodionova, T., \& Sanchez, I. 2014. Power and shareholder saliency, Working paper WP\#14-01: 1-25. Ottawa: Carleton Centre for Community Innovation.

Hendry, J. 2001. Missing the target: Normative stakeholder theory and the corporate governance debate. Business Ethics Quarterly, 11(1): 159-176.

Hennchen, E. forthcoming. Royal Dutch Shell in Nigeria: Where do responsibilities end? Journal of Business Ethics: 1-25.

Hernandez, M. 2008. Promoting stewardship behavior in organizations: A leadership model. Journal of Business Ethics, 80(1): 121-128.

. 2012. Toward an understanding of the psychology of stewardship. Academy of Management Review, 37(2): 172-193.

Hirschman, A. O. 1970. Exit, voice, and loyalty: Responses to decline in firms, organizations, and states. Cambridge: Harvard University Press.

Holzer, B. 2008. Turning stakeseekers into stakeholders: A political coalition perspective on the politics of stakeholder influence. Business and Society, 47(1): 50-67.

ICCR. 2014a. Roundtables. http://www.iccr.org/our-approach/shareholder-engagement-101/ roundtables, accessed 26th April 2014.

2014b. One million comments urge the SEC to stop secret corporate political spending. http://www.iccr.org/one-million-comments-urge-sec-stop-secret-corporate-politicalspending, accessed 7th October 2014.

. 2014c. Our approach. http://www.iccr.org/our-approach, accessed 20th October 2014.

Jamali, D. 2008. A stakeholder approach to corporate social responsibility: A fresh perspective into theory and practice. Journal of Business Ethics, 82: 213-231.

Jensen, M. C. \& Meckling, W., H. 1976. Theory of the firm: Managerial behavior, agency costs and ownership structure. Journal of Financial Economics, 3(4): 305-360.

Jones, T. M. \& Felps, W. 2013. Stakeholder happiness enhancement: A neo-utilitarian objective for the modern corporation. Business Ethics Quarterly, 23(3): 349-379.

Kang, N. \& Moon, J. 2012. Institutional complementarity between corporate governance and Corporate Social Responsibility: A comparative institutional analysis of three capitalisms. Socio-Economic Review, 10(1): 85-108.

Kraemer, R., Whiteman, G., \& Banerjee, B. 2013. Conflict and astroturfing in Niyamgiri: The importance of national advocacy networks in anti-corporate social movements. Organization Studies, 34(5-6): 823-852.

Lee, M.-D. P. \& Lounsbury, M. 2011. Domesticating radical rant and rage: An exploration of the consequences of environmental shareholder resolutions on corporate environmental performance. Business and Society, 50(1): 155-188.

Levit, D. \& Malenko, N. 2011. Nonbinding voting for shareholder proposals. The Journal of Finance, 66(5): 1579-1614.

Logsdon, J. \& Van Buren, H. 2009. Beyond the proxy vote: Dialogues between shareholder activists and corporations. Journal of Business Ethics, 87: 353-365.

Lozano, J. F. 2001. Proposal for a model for the elaboration of ethical codes based on discourse ethics. Business Ethics: A European Review, 10(2): 157-162.

Lydenberg, S. 2007. Universal investors and socially responsible investors: A tale of emerging affinities. Corporate Governance: An International Review, 15(3): 467-477. 
Mäkinen, J. \& Kourula, A. 2012. Pluralism in political corporate social responsibility. Business Ethics Quarterly, 22(4): 649-678.

Matten, D. \& Crane, A. 2005. What is stakeholder democracy? Perspectives and issues. Business Ethics: A European Review, 14(1): 6-13.

McCarthy, T. 1992. Introduction, Moral consciousness and communicative action. Cambridge: Polity Press.

McLaren, D. 2004. Global stakeholders: Corporate accountability and investor engagement. Corporate Governance: An International Review, 12(2): 191-201.

Monks, R., Miller, A., \& Cook, J. 2004. Shareholder activism on environmental issues: A study of proposals at large US corporations (2000-2003). Natural Resources Forum, 28(4): 317-330.

Moon, J., Crane, A., \& Matten, D. 2005. Can corporations be citizens? Corporate citizenship as a metaphor for business participation in society. Business Ethics Quarterly, 15(3): 429-453.

Moriarty, J. 2014. The connection between stakeholder theory and stakeholder democracy an excavation and defense. Business and Society, 53(6): 820-852.

Murphy, M. \& Arenas, D. 2010. Through indigenous lenses: Cross-sector collaborations with fringe stakeholders. Journal of Business Ethics, 94(1): 103-121.

North, D. C. 1990. Institutions, institutional change and economic performance. Cambridge, UK: Cambridge University Press.

NortonRose. 2011. Stock Corporation Act: Translation as at 1 December 2011. http:// www.nortonrosefulbright.com/files/german-stock-corporation-act-2010-englishtranslation-pdf-59656.pdf, retrieved 11th March 2015.

O'Dwyer, B. 2005. Stakeholder democracy: challenges and contributions from social accounting. Business Ethics: A European Review, 14(1): 28-41.

O'Rourke, A. 2003. A new politics of engagement: shareholder activism for corporate social responsibility. Business Strategy and the Environment, 12: 227-239.

Palazzo, G. \& Scherer, A. G. 2006. Corporate legitimacy as deliberation: A communicative framework. Journal of Business Ethics, 66(1): 71-88.

Phillips, R. A. 1997. Stakeholder theory and a principle of fairness. Business Ethics Quarterly, 7(1): 51-66.

Proffitt, W. T. \& Spicer, A. 2006. Shaping the shareholder activism agenda: institutional investors and global social issues. Strategic Organization, 4(2): 165-190.

Reed, D. 1999. Stakeholder management theory: A critical theory perspective. Business Ethics Quarterly, 9(3): 453-483.

Rehbein, K., Waddock, S., \& Graves, S. 2004. Understanding shareholder activism: Which corporations are targeted? Business and Society, 43(3): 239-267.

Rehbein, K., Logsdon, J. M., \& Van Buren, H., J. 2013. Corporate responses to shareholder activists: Considering the dialogue alternative. Journal of Business Ethics, 112(1): 137-154.

Richardson, B. J. 2008. Socially responsible investment law: Regulating the unseen polluters. New York: Oxford University Press.

Richardson, B. J. \& Cragg, W. 2010. Being virtuous and prosperous: SRI's conflicting goals. Journal of Business Ethics, 92(1 Supplement): 21-39.

Richardson, B. J. 2013. Fiduciary responsibility in retail funds: Clarifying the prospects for SRI. Journal of Sustainable Finance and Investment, 3(1): 1-16.

Rojas, M., M'Zali, B., Turcotte, M.-F., \& Merrigan, P. 2009. Bringing about changes to corporate social policy through shareholder activism: Filers, issues, targets, and success. Business and Society Review, 114(2): 217-252. 
Ryan, L. V. 2000. Shareholders and the atom of property: Fission or fusion? Business and Society, 39(1): 49-75.

Scherer, A. G. \& Palazzo, G. 2007. Toward A political conception of corporate responsibility: Business and society seen from a Habermasian perspective. Academy of Management Review, 32(4): 1096-1120.

Scherer, A. G., Palazzo, G., \& Matten, D. 2014. The business firm as a political actor: A new theory of the firm for a globalized world. Business and Society, 53(2): 143-156.

Schreck, P., van Aaken, D., \& Donaldson, T. 2013. Positive economics and the normativistic fallacy: Bridging the two sides of CSR. Business Ethics Quarterly, 23(2): 297-329.

Sjöström, E. 2008. Shareholder activism for corporate social responsibility: What do we know? Sustainable Development, 16: 141-154.

. 2010. Shareholders as norm entrepreneurs for corporate social responsibility. Journal of Business Ethics, 94: 177-191.

Smith, J. D. 2004. A précis of a communicative theory of the firm. Business Ethics: A European Review, 13(4): 317-331.

Soskice, D. 1997. Stakeholding yes; the German model no. In Kelly, G. \& Kelly, D. \& Gamble, A. (Eds.), Stakeholder capitalism: 219-225. London: Macmillan Press.

Stansbury, J. 2009. Reasoned moral agreement: Applying discourse ethics within organizations. Business Ethics Quarterly, 19(1): 33-56.

Stout, L. 2012. The shareholder value myth: How putting shareholders first harms investors, corporations, and the public. San Francisco: Berrett-Koehler Publishers, Inc.

Tkac, P. 2006. One proxy at a time: Pursuing social change through shareholder proposals. Economic Review, Federal Reserve Bank of Atlanta (Third Quarter): 1-20.

Unerman, J. \& Bennett, M. 2004. Increased stakeholder dialogue and the internet: Towards greater corporate accountability or reinforcing capitalist hegemony? Accounting, Organizations and Society, 29(7): 685-707.

USSIF. 2012. Report on sustainable and responsible investment trends in the United States. http://ussif.org/resources/pubs/, retrieved 1st December 2012.

Van Cranenburgh, K. C., Goodman, J., Louche, C., \& Arenas, D. 2012. Believers in the boardroom: Religious organisations and their shareholder engagement practices. http://www.3ignet.org/: International Interfaith Investment Group (3iG).

Vandekerckhove, W., Leys, J., \& Van Braeckel, D. 2007. That's not what happened and it's not my fault anyway! An exploration of managament attitudes towards SRIshareholder engagement. Business Ethics: A European Review, 16(4): 403-418.

Welcomer, S. A., Gioia, D. A., \& Kilduff, M. 2000. Resisting the discourse of modernity: Rationality versus emotion in hazardous waste siting. Human Relations, 53(9): $1175-1205$.

Whelan, G. 2012. The political perspective of corporate social responsibility: A critical research agenda. Business Ethics Quarterly, 22(4): 709-737.

Williams, C. C. \& Ryan, L. V. 2007. Courting shareholders: The ethical implications of altering corporate ownership structures. Business Ethics Quarterly, 17(4): 669-688.

Woods, C. \& Urwin, R. 2012. Putting sustainable investing into practice: A governance framework for pension funds. In Hebb, T. (Ed.), The Next Generation of Responsible Investing. Dordrecht: Springer. 